\title{
Literature Review: Research Reflection of Financial Statements Fraud Detection Methods in Indonesia
}

\author{
Putri Intan Prastiwi and Payamta
}

\section{ABSTRACT}

This study aims to identify methods in the detection of fraud in financial statements conducted by researchers in Indonesia. This research has been published on the website of the Ministry of Research and Technology with the SINTA 1 and SINTA 2 indexes. This research was conducted with a literature study on financial statement fraud in Indonesia. The research method used is a descriptive qualitative method by taking data from literacy studies on the research of fraud detection methods in Indonesia. The results of this study indicate that the fraud detection method used in financial reports in Indonesia is using the fraud Triangle method. The article of these studies is expected to provide input, insight, and information to all parties such as company management, auditors, and users of financial statements about various methods of detecting financial statement fraud in Indonesia.

Submitted : August 06, 2021

Published : August 28, 2021

ISSN: 2507-1076

DOI: $10.24018 /$ ejbmr.2021.6.4.1037

Putri Intan Prastiwi*

University of Sebelas Maret Surakarta, Indonesia.

(e-mail: putriintanprastiwi ${ }^{@}$ gmail.com)

Payamta

University of Sebelas Maret Surakarta, Indonesia.

(e-mail: payamtaakuntan@gmail.com)

Keywords: Financial Statement Fraud, Fraud, Detection of Fraud.

*Corresponding Author

\section{INTRODUCTION}

The current financial statement fraud scandals are common. The increase in these cases must be an important concern for companies to improve control aimed at preventing fraud. Several International scale companies that had good perceptions in the public were also damaged due to financial statement fraud. Companies like WorldCom, Enron, Iyco are examples of leading companies that were devastated by financial fraud. Fraud has resulted in the loss of investor confidence in the capital market. Financial statements are expected to provide information about the company's financial performance and how the company's management is accountable to the owner (principal). The financial statement shows a form of company management accountability to investors and stakeholders. Financial statements are used for decision-making, so the reliability of a financial statement is needed. Financial statements are a means of communicating financial information to parties outside the company [1]. According the Association Of Certified Fraud Examiners (ACFE) Fraud is an act of fraud or error made by a person or entity who knows that the mistake has resulted in several benefits that are not good for individuals and entities. Fraud is very detrimental to various parties because the resulting financial statements are not following the actual conditions so that they will lose the reliability of these financial statements [2]. Fraud occurs due to lack of supervision from the relevant board, selfish management, ineffective internal audit functions, too lenient regulations, inappropriate business decisions of senior managers, disclosure of financial statements that are not following company conditions, and lack of stakeholder attention [12]. Research on the method of financial statement fraud detection has been investigated by researchers around the world. The method of detecting financial statements using the fraud triangle theory method based on the theory of Creseey [15], [4]. Financial statement fraud detection with the fraud diamond theory based on the theory of Wolfe dan Hermanson [6],[11]. Detects financial statement fraud with a beneish model using 20 financial ratios [13]. Detection of fraudulent financial statements using ratio analysis method with 8 to 10 financial ratios [5]. Red flag method for detection of financial statement fraud [3]. The method of detecting financial statement fraud with trend ratio analysis namely changes from year to year is the center of research [9]. Based on the overall research, it is a fraud detector of financial statements abroad. Thus, in Indonesia, there has been no research that discusses methods of detecting financial statement fraud that is most widely used. So, the researchers are interested in researching literacy studies reflecting methods of financial statement fraud detection in Indonesia.

\section{LITERATURE REVIEW}

\section{A. Fraud}

SAS No.99 American Institute of Certified Public Accountant (AICPA) states that fraud is an intentional action can cause fraudulent financial statement [1]. Association of Certified Fraud Examiners fraud is an unlawful act that is carried out intentionally for a specific purpose such as manipulation or give report face to other parties for personal or group gain which directly or indirectly harms the other party [2].

\section{B. Fraud Triangle Theory}

Fraud triangle introduced by Statement of Auditing Standard (SAS) from American Institute of Certified Public Accountant [1]. There are three elements in fraud triangle 
who can doing for detection fraud of them: The first element is pressure [4]. Pressure yaitu occurs when someone pushes to commit fraud and manipulation due to certain conditions [1]. Pressure factors involve financial stability, personal financial need, external pressure, dan financial target [1]

Opportunity is an act of fraud occurs when there is an opportunity for the perpetrator commit fraud due to weak supervision of a company [1]. Opportunities can stem from the nature of the company's industry and ineffective internal controls [9].

Rationalization is Fraud occurs because someone who commits fraud has a justification for thinking in the fraudulent act that is character and attitude or ethical values who allow fraudulent act [1].

\section{Fraud Diamond}

Teori fraud diamond state by Wolfe dan Hermanson. Fraud diamond that is perfection teori Fraud Triangle with adding one category that is capability as the fourth element besides pressure, opportunity, rationalization. Capability has a strong influence in fraud [6]. The person who commits the fraud must have the ability the ability to recognize an open door as a golden opportunity and to take advantage of it not once but many times [6].

\section{The Crowe Fraud Pentagon}

Teori Crowe Howarth known as theory Fraud Pentagon yaitu refinement of theory Fraud Diamond to adding one category that is arrogance [7]. arrogance adalah an attitude of superiority over the rights they have and feel that internal control or company policy does not apply to him. Arrogance is having a lack of conscience and arrogance. If someone has a high level of arrogance, it can trigger fraud [10]

\section{METHOD}

\section{A. Types and Sources of Data}

The type of data to be used in this research is secondary data. Secondary data were obtained from conducting literature studies from research on fraudulent financial statements published on the website of the Ministry of Research and Technology's paper, namely https://sinta.ristekbrin.go.id/journals and accredited B of SINTA 1 and SINTA 2 indexes. Paper data collection by using keywords of accounting, economics, auditing, finance, fraud, fraudulence

\section{B. Data Collection Techniques}

Data collection techniques used to obtain data are as follows.

Documentation documents are records of past events. Documents can be in the form of writings, pictures, or monumental works of a person. The documentation in this research will be in the form of notes on the financial statements of the central government [16].

Literature study Literature study is the main material in secondary data research. Researchers obtain data related to the problem being studied through books, papers / literature, the internet, and other tools related to the analysis of central government financial statements [16].
Research Model This research model is to use a literature review of research model known as synthesis research, which combines the results of existing studies and analyzes them then draws a general conclusion from the analysis that has been done. This research uses the vote-counting method. Vote counting is a qualitative method with a narrative review and descriptive review and a method of selecting and counting, also called combining probabilities [8], [17]. Entered the review score box used to draw qualitative conclusions about the focus of relationship correlation is very different from 0 or not) from the results of combining research results [12]. Some researchers consider vote counting, and other researchers separate vote counting as an alternative to quantitative reviewing methods primarily because these methods did not analyze the effect of size.

\section{RESULT}

This study was conducted effectively for approximately two months to search for data, as well as to perform data processing. This research was conducted to answer several research questions, including the fraud detection method used to detect which fraud is most widely used in Indonesia. The research data uses secondary data obtained from the page of https://sinta.ristekbrin.go.id/journals with SINTA 1 and SINTA 2 indexes. The researcher conducted data searches using the keywords of accounting, economy, auditing, finance, fraud, fraudulence. The number of papers downloaded during the study was 58 papers according to the criteria including from the results of research on fraud detection methods, it appears that the most widely used fraud detection method is to use the fraud triangle theory is 10 papers $(17 \%)$, both auditors' perceptions are 8 papers $(14 \%)$, then the fraud diamond theory is 6 papers $(10 \%)$ and the beneish model is 6 papers $(10 \%)$, the Scepticism method is 5 papers $(9 \%)$, while the Pentagon theory is 4 papers $(7 \%)$, then Gone Theory is 3 papers ( $5 \%)$, as well as the red flag method, auditor experience, and gender, are respectively 2 papers (4\%), and the rest using other methods such as personal financial need, agency theory, ratio analysis, workload, independence, competence, professionalism. So, it can be concluded that the most widely used fraud detection method is the fraud triangle theory.

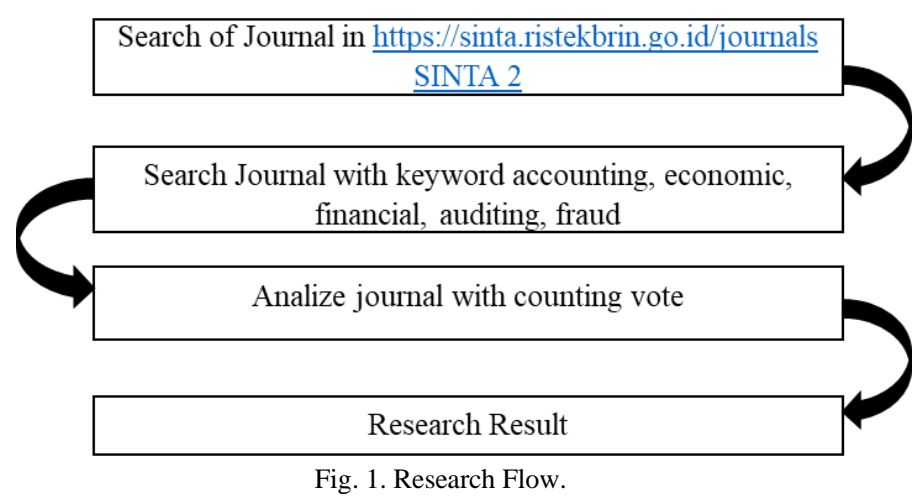

\section{A. Discussion}

Researchers have searched for papers from the page of https://sinta.ristekbrin.go.id/journals with the indexes of Science and Technology Index (SINTA) beside SINTA index 
1 and SINTA index 2 during the research period is effective for 35 days to search for papers from various journals in Indonesia. The results obtained were 58 papers. From all these papers, it can be seen that:

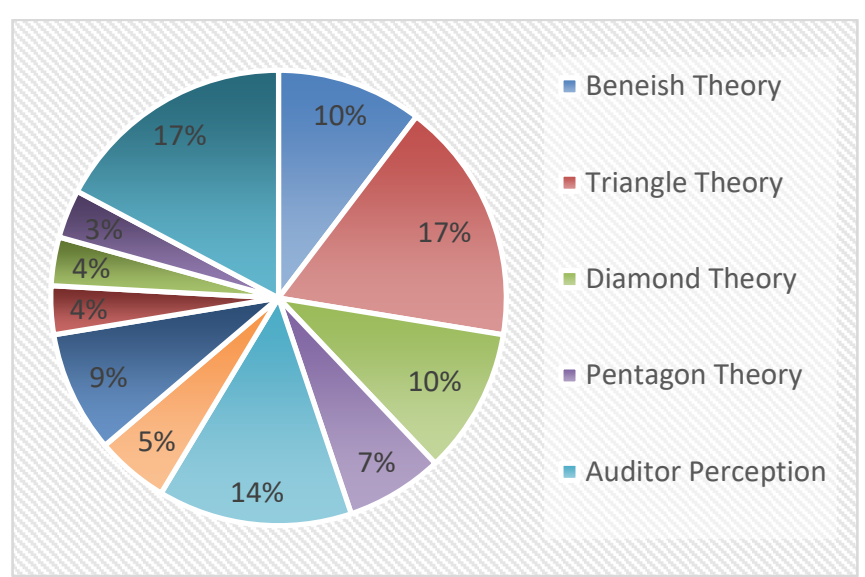

Fig. 2. Detection Fraud Method.

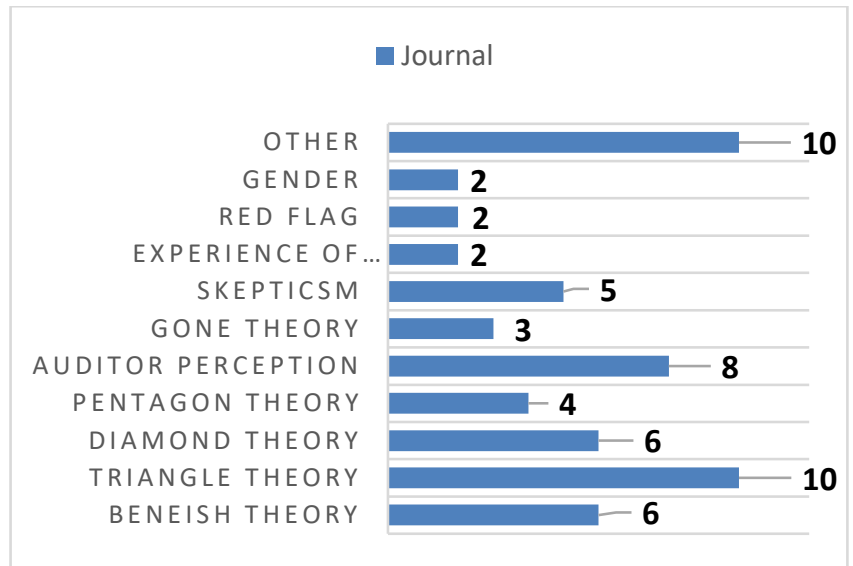

Fig. 3. Detection Fraud Method.

The researches are related to the method of detecting financial statement fraud. Some reasons for the lack of research on fraud on the website of the Ministry of Research and Technology https://sinta.ristekbrin.go.id/journals with the indexes of the SINTA 1 and SINTA 2 because the publication standards on the index must be reviewed by competent reviewers so that published research is expected to be a reference for further research. And if the paper has been published on that page, it can be said that the paper is fit to be submitted to an International Journal. Fig. 3 illustrates that the fraud detection method using the fraud triangle analysis is most widely used rather than the use compared to the fraud diamond and the fraud pentagon. It was shown that there were 10 researchers conducting research on the fraud triangle, the fraud diamond theory of 6 researchers, and 4 researchers of the fraud pentagon. The difference from this analysis is the fraud occurs because there are three conditions namely pressure (pressure) or incentive that encourages someone to commit fraud such as personal problems related to financial conditions [4].

Second, namely the opportunity (opportunity), there is an opportunity for fraud to occur due to the weak internal control of the company so that it provides an opportunity for the perpetrator to commit fraud. The third is rationalization (rationalization), namely the attitude of a person who rationalizes or justifies the act of fraud. Wolfe and
Hermanson [6] stated that the act of fraud in its implementation will meet the three elements of the fraud triangle expressed by Creessey namely the perceived pressure, opportunity, and rationalization, the equation of fraud is not complete unless all four elements, namely capability (capability).

The fraud is not possible without the appropriate persons to carry out the fraud or fraudulence. The newest concept that is developing is the fraud pentagon. The fraud pentagon theory (Crowe's fraud pentagon theory) seeks to better capture the factors that influence the occurrence of fraudulent behavior. The fifth element in the fraud pentagon concept is external regulatory influence. The fifth element in question is arrogance. Fraud occurs because of low control in the company. In this study, the most widely used method of detecting financial statement fraud using the fraud triangle approach, the second is the fraud diamond, and the last is the pentagon fraud. It can be seen that the fraud pentagon is not well understood, so researchers prefer to examine the fraud diamond and fraud triangle rather than the fraud pentagon.

Apart from the fraud triangle, diamond, and pentagon detection methods that are widely used by researchers include personal financial need, agency theory, analysis of ratios, workload, independence, competence, professionalism which are signs of fraud in an entity.

\section{CONCLUSIONS, IMPLICATIONS, AND SUGGESTIONS}

The conclusions in this study is that the most widely used detection method is the analysis method using the fraud triangle. Implications of this research can be used as a reference for further research, as well as the bias used by auditors or company management to detect fraud early. Suggestions for this research are any development in research such as to what extent effectiveness of each detection method. Especially the detection method using financial statement analysis tools due in Indonesia the average detection method is still numerous using conventional methods with using a questionnaire so that the subjectivity is still high.

\section{ACKNOWLEDGEMENT}

The author would like to thank the Master of Accounting (MAKSI) postgraduate program from the State University of Sebelas Maret Surakarta for its support. This research comes from data from the Ministry of Research and Higher Education of the Republic of Indonesia from the Sinta 1 and Sinta 2 journals with the website Science and Technology Index (SINTA) https://sinta.ristekbrin.go.id/journals

\section{REFERENCE}

[1] AICPA. (2002). "AU Section 316 Consideration of Fraud in a Financial". October, 99, 113, 167-218.

[2] ACFE Indonesia Chapter. (2019). "Survei Fraud Indonesia 2019". ACFE Indonesia, 76.

[3] Arens, Alvin A. And Loebecke, J. K. (2005). "Auditing and Assurance Service". Jakarta : Erlangga.

[4] Cressey, D.R. (1950), "The criminal violation of financial trust", American Sociological Review, Vol. 15 No. 6, pp. 738-743.

[5] Guan, L., Kaminski, K. A., \& Sterling Wetzel, T. (2004). "Can 
financial ratios detect fraudulent financial reporting?". Managerial Auditing Journal, 19(1), 15-28. doi:10.1108/02686900410509802.

[6] Hermanson, W. dan. (2004). "The Fraud Diamond: Considering The Four Element of Fraud". CPA Journal. 74.12: 38-42. The Fraud Diamond: Considering The Four Elements of Fraud. The New York State Society of CPAs.

[7] Horwath, C. (2011). "Why the Fraud Triangle is No Longer Enough". Horwath, Crowe LLP.

[8] King, W. R., \& He, J. (2006). "A meta-analysis of the technology acceptance model. Information and Management", 43(6), 740-755. https://doi.org/10.1016/j.im.2006.05.003.

[9] Kotsiantis, S., Koumanakos, E., Tzelepis, D., \& Tampakas, V. (2006). using Data Mining. 3(2), 104-110.

[10] Meliana, M., \& Hartono, T. R. (2019). "Fraud Perbankan Indonesia: Studi Eksplorasi". presented at the expert national seminar 2, 2, 1-7.

[11] Omukaga, K. O. (2019). "Is the fraud diamond perspective valid in Kenya ?". https://doi.org/10.1108/JFC-11-2019-0141.

[12] Pickard, L. M., Kitchenham, B. A., \& Jones, P. W. (1998). "Combining empirical results in software engineering. Information and Software Technology", 40(14), 811-821. https://doi.org/10.1016/S09505849(98)00101-3.

[13] Repousis, S. (2016). "Using Beneish model to detect corporate financial statement fraud in Greece. Journal of Financial Crime", 23(4), 1063-1073. https://doi.org/10.1108/JFC-11-2014-0055.

[14] Sahiti, A., \& Bektashi, M. (2015). "Detection Techniques of Fraud in Accounting. European Journal of Economics and Business Studies", 2(1), 96. https://doi.org/10.26417/ejes.v2i1.p96-101.

[15] Skousen, C. J., Smith, K. R., \& Wright, C. J. (2015). Article information: (Issue 99).

[16] Sugiyono. (2009). "Research Methods Quantitative, Qualitative and R\&D", Bandung: Alfabeta.

[17] Wilson, E. J. (1994). "Meta-analytic procedures for social research. Journal of Business Research", 29(2), 163-165. https://doi.org/10.1016/0148-2963(94)90020-5. 